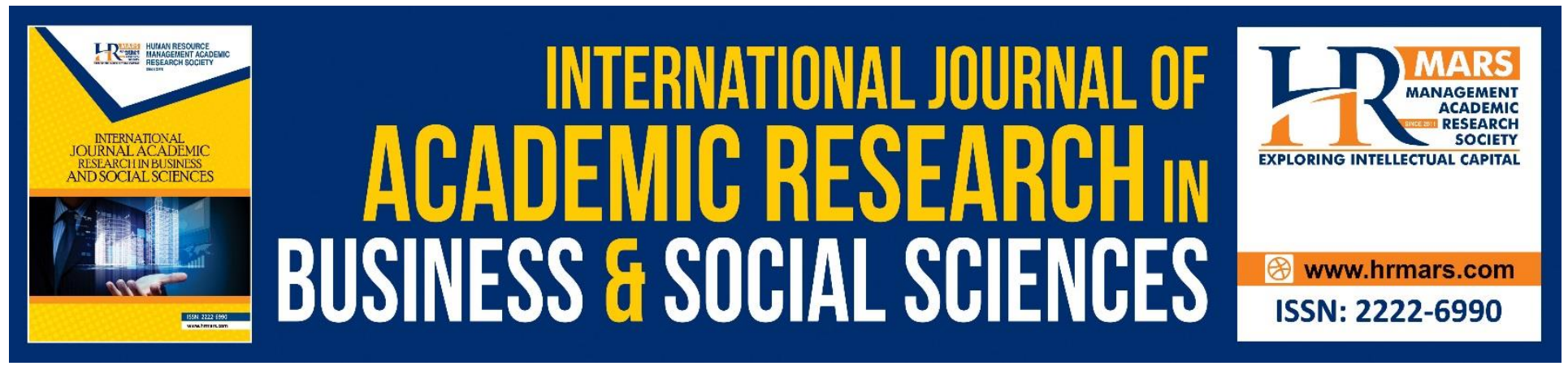

\title{
Profit-Taking Rate Guideline Based on Fiqh Muamalat Perspective
}

Jasni Sulong \& Fathullah Asni

To Link this Article: http://dx.doi.org/10.6007/IJARBSS/v8-i7/4345

DOI: $\quad 10.6007 /$ IJARBSS/v8-i7/4345

Received: 24 June 2018, Revised: 23 July 2018, Accepted: 31 July 2018

Published Online: 05 August 2018

In-Text Citation: (Sulong \& Asni, 2018)

To Cite this Article: Sulong, J., \& Asni, F. (2018). Profit-Taking Rate Guideline Based on Fiqh Muamalat

Perspective. International Journal of Academic Research in Business and Social Sciences, 8(7), 340-348.

Copyright: (C) 2018 The Author(s)

Published by Human Resource Management Academic Research Society (www.hrmars.com)

This article is published under the Creative Commons Attribution (CC BY 4.0) license. Anyone may reproduce, distribute, translate and create derivative works of this article (for both commercial and non-commercial purposes), subject to full attribution to the original publication and authors. The full terms of this license may be seen

at: http://creativecommons.org/licences/by/4.0/legalcode

Vol. 8, No. 7, July 2018, Pg. 340 - 348

http://hrmars.com/index.php/pages/detail/IJARBSS

JOURNAL HOMEPAGE

Full Terms \& Conditions of access and use can be found at http://hrmars.com/index.php/pages/detail/publication-ethics 


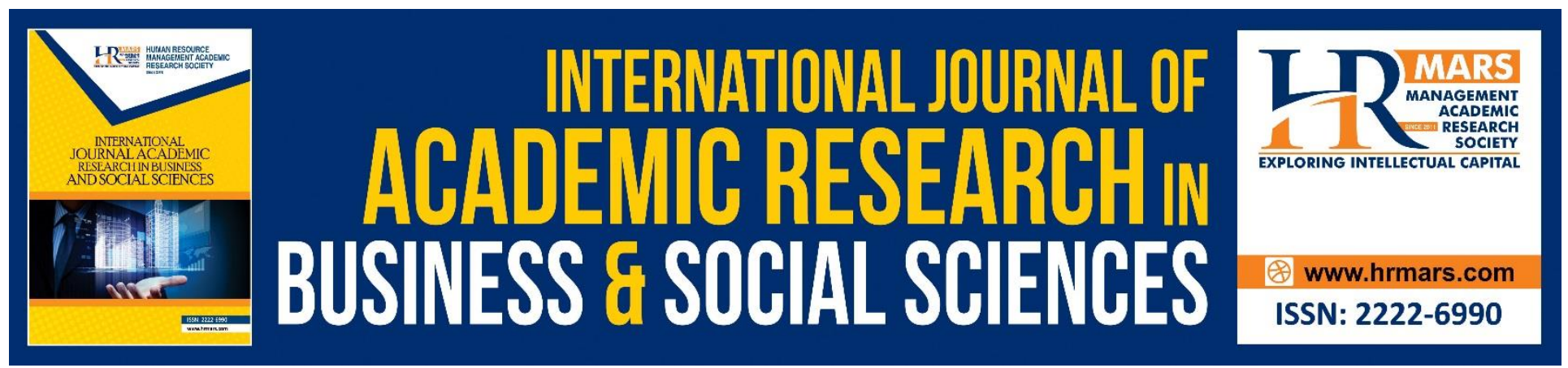

\title{
Profit-Taking Rate Guideline Based on Fiqh Muamalat Perspective
}

\author{
Jasni Sulong \& Fathullah Asni \\ School of Humanities, Universiti Sains Malaysia \\ Email: jasni@usm.com
}

\begin{abstract}
The absence of profit-taking rate guideline in Islam has caused misunderstanding and manipulation among sellers or businesspersons who deliberately take advantage by charging an excessive profit rate. Consequently, it has increased burden to customers in term of purchasing power as well as has raised the price of goods. Based on the issue, this study aimed to investigate profit-taking rates from muamalat perspective. The methodology of the study is qualitative, in which datas and informations were collected through literature studies and then scrutinized using content analysis. The findings of this study show that profit-taking standard rates are based on local customs, such as double of the capital. The study discovered that government can control the price of goods and rate of profitability taken by entrepreneurs in order to stabilize the price of goods in the market and avoid any kind of manipulation activities. The findings also show that profit-taking guide follows the half, double, or triple profit-taking rate based on facts of the additional costs incurred. Hence, if profit-taking activities is multiplied extra than the normal standard, it can lead to the implication of ad'afan muda'afah. The results of this study are also supported by concrete support methods, comprising maqasid al-syariah, wasatiyyah, and ihsan.
\end{abstract}

Keywords: Profit, Islam, Maqasid Al-Syariah, Wasatiyyah, Ihsan.

\section{Introduction}

In every business activity, profit is its ultimate aim except to those who doing charity. The concept is well-understood and has been applied for a long time since barter system era, where both parties get benefit from the transaction. Likewise, Islam promotes business activities in order to gain profit as well as to benefit their life in fulfilling needs and necessities. The income or profit gain will be used to support the living of individual, family, societies as well as to satisfy religious demands such as donation, charity, waqf, and zakat. Therefore, profit-taking is inevitable in any transaction amidst economic constraints among Muslim and non Muslim nowadays as long as its compliance to the shariah rules and laws (Mohamad, 2002). In our daily live, individuals not only become as trader but also as consumer. Therefore, the topic is really involve societies to create an awareness towards excessive profit-taking rate nowadays. As decided by the Court of Justice of European Union in 1978, charging a price with an excessive rate is an abuse (Waghe, N. et. al., 2015). Hence, the exploitation 
INTERNATIONAL JOURNAL OF ACADEMIC RESEARCH IN BUSINESS AND SOCIAL SCIENCES Vol. 8, No. 7, July 2018, E-ISSN: 2222-6990 @ 2018 HRMARS

can be prevented by educating publics as well as by advising government to take a step ahead to resolve the matter.

Nevertheless to recent, none profit-taking rate have been set by the shariah as well as government to be as a guideline in commercial activities. It have caused some problems when some sellers have taken an advantage as well as manipulating the price. Ideally, there is hadith that the Prophet (pbuh) prohibited any acts of fixing the price to ensure the process of demand and supply occurs fairly. However, commercial activities during those days dissimilar to recent days as businessmen at that time were among Companions who were well-known for their honesty and accountability. Thus, they were very honest in profit-taking, follow good customs ('uruf sahihah) and not manipulate the price (Ibn Majah, 2009). However, today's situation is vastly different, as many businesspersons have misunderstood the context of the hadith. They assumed that it was their exclusive rights to charge at any price-value as long as they can make a profit. Therefore, they simply set price without any calculation and mark up price without bearing any cost involved, except for their own wants which clearly has abandoning the 'urf. Consequently, all of the activities has persecuting as well as oppressing customers. Likewise, the existence of price imbalance in the market such as unreasonable price have taken place due to monopolies (ihtikar), conspiracy among sellers as well as oppressive by charging a price without reasonable ground.

The awareness of the issue is essential when Bank Negara Malaysia (2015) reports of great concern over the rising cost of living as a result of the increasing price of goods. Similar reports were made by the New Straits Times (2017) and Astro Awani (2018). In addition, Bank Negara records in 2017 show that a total of 130,690 house units were unsold, and the number is the highest in the decade (Ling, et al. 2017). The failure to sell is due to several factors; among them is high profit-rates taken by developers followed by high interest charged by banking institutions. In the early days of Islam, government have taken a step in which during the period of Umar al-Khattab, the government had set the price of goods due to the dishonesty of some of the traders in profit-taking. However, it was only limited to particular goods that determined by the government (Ibn Qudamah, 1405H) such as of basic needs. Hence, all these point of view have remarked the need in determining profit-taking method to ensure maslahat to customers as well as traders. Therefore, the objective of this study is to investigate as well as to set a parameter on the profit-taking rate based on the Islamic muamalat perspective.

If we review the above topics, many previous studies have shown that the jurisdiction in setting price for goods is by the government (i.e. Hasan, 2006; Ya'qubi, 2000; Faridah, 2011). With more focused, the study had initiated more on debates about the mechanism of gaining profit through contracts which are allowed by the shariah. For instance, a study conducted by Muhammad (2007) which discussed on profit-taking through the contract of al-murabahah li al-amr bi al-syira'. Mohamad (2002), in his study has opined about the characteristics of profit, that is, to avoid of making profits from illegal sources such as usury. Hence, this study aims to focus on developing the concept of profit-taking rate in Islam based on arguments through maqasid syariah, wasatiyyah, and ihsan.

\section{Profit-taking Based on Muamalat and Economics Perspectives}

Profit means a surplus or additional gain on something (Malik, n.d.). It is a revenue from enterprise, business or other commercial activities, which is extra from the actual capital and other expenses (Dewan, 2010). This additional increase is also explained as a return that acquired from business. The profit-income is considered as an achievement gained by an entrepreneur of his endeavour in 
INTERNATIONAL JOURNAL OF ACADEMIC RESEARCH IN BUSINESS AND SOCIAL SCIENCES Vol. 8, No. 7, July 2018, E-ISSN: 2222-6990 @ 2018 HRMARS

business transaction or commercial activities. Conceptually, Islam permits profit-taking (Quran, 2: 16) as well as Muslims are urged to seek additional capital from business ventures, working on something halal and satisfying their needs from an exchange of goods. In fact, the Messenger of Allah (pbuh) encourages Muslims to work on their own hands, like collecting woods and selling them for income (Syawkani, 1993).

Profits are the bestowal of sustenance from Allah SWT. The more the sustenance, the more benefit to the people. The income or profit can be used to support families, buy goods, satisfy needs as well as assist people. In this term, sustenance and profit refer to the same meaning, that is, surplus earned from the endeavour undertaken. Syarbini (1997) states that profit is indeed a goal of business activity through the exchange of goods with cash, or goods with goods. The same view is expressed by Ibn Khaldun (1958) that selling and buying activity is an endeavour to gain profit or in other words, to expand a person's assets. However, Islam prohibits from making profits based on illegal transactions or from nothing. According to Mohamad Idris (2002), there are four elements which are prohibited in profit-taking, that is, riba transactions (usury), ihtikar (monopoly), gharar (uncertainty) and ghabn fahisy (fraud).

Meanwhile, in terms of economics, profit is a balance obtained by a manufacturer once he or she has satisfied all costs of expenditure in the trade activity (Yahaya, 1985). The balance is a surplus of the actual capital that a person has, whereby it shows that there is an increase in the amount of property previously held. According to Tabari (1980), a business person would gain profit when he or she changes his or her commodity with more valuable commodities. On the contrary, if he or she changes his or her commodity with a cheaper commodity, then he or she will suffer losses. In other words, an increase in returns obtained from the original price of capital is known as profit.

In general, profit-taking occurs in loans and also in buying and selling. In any case, the seller has the rights to gain profits. However, in Islam, the rights are bounded by certain ethics, morals, and restrictions. Hence, an extra charge from loan activity may be a profit to a lender, but in Islam, it is known as usury which is prohibited by the shariah. Meanwhile, an extra charge on goods sold is also profit to the seller and this is permitted by the shariah. In short, shariah permitted profits from purchasing activities rather than through lending as it involve usury. In the Quran (Quran, 2:275), Allah permitted the sale and forbade riba. The hadith went further that, every loan which attracts benefit is riba. Therefore, riba is unjustified increase of capital for which no compensation is given.

This key of point is asserted by El-Islamy (2014) who stated that Islamic muamalat systems does not allow the economy to be based on the principle of usury or profit-taking on lending as the foundation of overall economic activities. It is obvious that the fundamentals of Islamic economics discourage the usage of lending as a means of economic development. The loan function should be aimed at charity and welfare instead of commercial purposes. In fact, when the Messenger of Allah was asked; what is the best income? The Prophet Muhammad (pbuh) replied that income of a person from his manual labour and every authorized trade. This answer is in line with the word of Allah in Surah al-Baqarah, verses 275, 278, and 279, more over to consume usury, doubled and multiplied (Quran, 3: 130). The principle of justice and balance in the muamalat and Islamic economy becomes inhibited with extreme profits which is tyrannical and oppressive.

Clearly, Islam rejects the profits achieved through unlawful means such as usury or uncertainty. Likewise, being unaccountable and despotic by hoaxing the market price through price manipulation (Rawwas, 2002). The shariah emphasizes on fairness and accountability in muamalat as a form of social responsibility between merchant and consumer (Quran, 4: 58). 
INTERNATIONAL JOURNAL OF ACADEMIC RESEARCH IN BUSINESS AND SOCIAL SCIENCES Vol. 8, No. 7, July 2018, E-ISSN: 2222-6990 @ 2018 HRMARS

\section{The Rate of Profit-taking}

Basically, profit-taking in trading is a necessity based on proposition of the Quran, hadith, and consensus of Muslim scholars. In the Quran, Allah SWT says: "O you who believe! Eat not up your property among yourselves in vanities: but let there be amongst you traffic and trade by mutual goodwill" (Quran, 4: 29). This verse suggests that it is lawful in Islam to take the property of others through profit or exchange of goods in a transaction of sale (Razi, 1420H). The necessity of taking profit is mutually agreed (ijma') by the Islamic scholars (Syawkani, 1993).

Meanwhile in hadith insinuation, it is narrated that the Prophet (pbuh) gave 'Urwah one dinar to buy a goat, but Urwah used it to buy two goats. Then he sold one of the goats with the price of one dinar. Thus he came back bringing a goat and a dinar with him. The Prophet (pbuh) then prayed for blessing for him (Bukhari, 1422H). The hadith indicates that profit is among the sustenance that Allah gives, thus basically, Islam does not limit the profit-taking rate in trading. It is clearly allowed to take double-fold profits, as mentioned in the above hadith as long as it reasonable, at the market price, not the staple need of people as well as the profit is not far from custom ('uruf). In addition, the profit is not a result of hoarding, which caused the scarcity of the goods thus increasing its price.

In terms of profitability limits under Muslim scholar consensus, Majma' Fiqh al-Islami have decided on 1988 that in the principles of shariah there are no certain limits were set on profit-taking in business. However, government has authority to set certain ceiling price on goods as well as setting the rate of profit-taking in the event of price imbalance in market that would suppress people with unreasonable prices due to monopolies, conspiracies, excessive prices as well as fraud in the economic activities. Here, government can intervene in order to create justice and equilibrium. Besides that, the Islamic scholars also exclaim not to overdo profit as the Prophet (pbuh) encourages in trade with good manners as he said, "Allah SWT blesses a generous servant in business." (Ibn Majah, 2009). Saudi Fatwa Institute (2018) also at the same tune which encourage to make ease with people in buying and selling, taking a small profit and helping each other in a good course.

According to Abu Hanifah, extreme profits are those that surpass the market prices (Malik, n.d.). If it occurs, the state of oppression, tyranny and unfairness will be felt by the customers. Since the principle of muamalat requires the pleasure of Allah SWT, every business transaction must be fair and equitable so that it is in parallel with the human needs and subsequently, receive the blessings of Allah SWT. Therefore, any circumstance that work vice-versa should be stopped in guaranteeing society's welfare.

To achieve the fairness and equity, the method of profit-taking must be in line with the risk and profit, as stated in the Figh method that the profit should be in parallel with the loss or the loss should be in parallel with the profit (Taimiyyah, n.d.). Hence synthetically, this illustrates that a multiplied profit-taking that is incomparable with its loss is in contrary with the Islamic teaching. That explains grounds that a multiplied profit-taking is identical to usury which is prohibited in Islam because it leads to tyranny and oppression. Thus based on this discussion, the Islamic muamalat outlines several methods in profit-making, so that it is not extreme, such as the following:

1) The price of the item is set at market price. Hence, profits and liabilities are consistent and fair between the seller and the buyer in which any party receives the same profit or liability when dealing with anyone.

2) Profit rate is based on local custom such as at double of the capital price. The principle is to appreciate the effort, cost of acquisition and cost of liability financed by the seller in acquiring and storing the goods. 
INTERNATIONAL JOURNAL OF ACADEMIC RESEARCH IN BUSINESS AND SOCIAL SCIENCES Vol. 8, No. 7, July 2018, E-ISSN: 2222-6990 @ 2018 HRMARS

3) The government can control the price of goods and profit level of the entrepreneur so that price of goods can be stabilized in the market and any act of manipulation can be avoided. Hence, price of items will remain consistent and the buyer is assured from being deceived. Profit-taking at half-, double-, or triple-profit rate based on the details of the additional cost incurred. Hence, if the price is more than that, then it can lead to the implication of doubled and multiplied (ad'afan muda'afah).

This profit setting is also supported by some other concepts, which is a measure of human deeds and relationships, namely maqasid al-shariah, wasatiyyah and ihsan.

\section{Profit According to Maqasid Shariah, Wasatiyyah and Ihsan}

Maqasid shariah is an important element in the determination of profit in a transaction. This is because the maqasid shariah becomes the objective of shariah, the law giver, particularly when it involves problems concerning the muamalat. Maqasid shariah is a shariah-defined goal to be achieved for the benefit of mankind which includes the observe of religious, soul, intellectual, offspring and property, as well as to avoid any harm for humans (Ghazali, 1997). According to Syatibi (1997), there are three levels of goodness (maslahat) that need to be protected, that is orderly, the essential needs (daruriyyat), complementary needs (hajiyyat), and embellishment needs (tahsiniyyat). Daruriyyat requirement involve the preservation of five fundamental needs. The absence of those elements can lead to harm and destruction in individual and society. The necessity of hajiyyat refers to a complement that facilitates life's affairs, without which life will be difficult even though there are no elements that can lead to destruction. Meanwhile, tahsiniyyat is a embellish requirement that based on the tendency of manners and custom in society. However, its absence will not lead to the destruction and difficulty in the life of society as it is only a side needs.

Based on the above maqasid shariah, profit-taking method should also take into account the position of daruriyyat, hajiyyat, or tahsiniyyat. Hence, profits taken from transactions involving the categories of daruriyyat are certainly different from transactions involving hajiyyat categories. For example, the maqasid preserves lives in the category of daruriyyat, whereby without it no human being can continue living such as food, drinks, medicine, clothing and residence. Thus, this should be given more attention by the government (Saleh et al., 2012) in setting the market price. Hence, every profits made in the category of goods and services must bring benefit and welfare to them equally.

Meanwhile, wasatiyyah in the transaction can be understood as moderate and affordable. It originated from the word "wasat" which means average or middle (Madkur, n.d.). According to Hashem (n.d.), wasatiyyah refers to every matters that are in the middle, so there are not in an excessive (extreme) or deficient way. Likewise, Qaradawi (1997) defines wasatiyyah as something that deserves an appropriate step by taking a middle path approach to avoid an extremes attitude. Meanwhile, Razi (1420H) interpreted the word "wasat" as justice, fairness approach, being balanced and fair. This concept seems to differ with the Jews and Christians who are excessive in all matters, particularly involving religious and muamalat issues such as usury, exaggerating in profits, and often do trickery that are prohibited (Mazuki et al., 2013). Hence, the wasatiyyah concept plays a very important role in profit-taking to ensure that it is not being done extremely and that it is balanced and fair.

Subsequently, ihsan means doing things better and in excellent manner. While in transaction among people, it means to do good, to improve the affairs, and to diligently in implementing (Madkur, n.d.). According to Dewan (2010), ihsan means goodness, virtue, good deeds and 
INTERNATIONAL JOURNAL OF ACADEMIC RESEARCH IN BUSINESS AND SOCIAL SCIENCES Vol. 8, No. 7, July 2018, E-ISSN: 2222-6990 @ 2018 HRMARS

generosity. These meanings are the understanding excerpted from the Quran and al-Hadith (Mohamad Yusof et al. 2015). In the Quran, Allah SWT orders Muslims to do good when it comes to dealing among the fellow human beings (Quran 4: 36). Allah SWT also encourages to do good in managing property (Quran 2: 195). The act of ihsan brings a tremendous impact because it creates God's love for the servant and the well-being of human life (Zuhaili, 2011). Zuhaili (2011) also states that the demand for ihsan is in every matter, particularly involving worship, muamalat and morals. Besides the Quran, the concept of ihsan is also claimed in the hadith of the Prophet (pbuh), as narrated that "If you must slaughter, slaughter in the best possible manner, sharpen your knife every time before you slaughter but not in front of the animal to be slaughtered. Do not slaughter an animal in the presence of other animal, and feed and rest the animal before slaughter.". Hence, if goodness to be applied for animal, then in the case of human, it is definitely preferred more.

According to Mohamad Yusof (2015), the ihsan approach is very important in the field of economy as Islam demands the fellow human beings to help each other in fulfilling their needs. It is not only related to the rights of sellers and buyers, but also in relation to goodness, virtue, and generosity. Fulfilment of the rights of others in matter of goods is an 'ibadah (worship) which likens the zakat, charity, infaq and sadaqah which helping to reduce burden of public from any oppression and satisfy their needs. According to Qaradawi (2012), the Islamic approach through ihsan in profittaking is in contrast to conventional economic systems, particularly capitalist economics. The capitalists consider property as belonging to the owner's absolute property and the other person does not have the right to intervene in the possession of the property. As a result, they are free to define profit-taking without tolerance, using fabricated calculations and ignoring the customer's welfare. Even if there is a compassion, it exists without any ihsan, but often used as a marketing strategy to enhance the image of the the dealer in promoting the business.

\section{Conclusion}

Although the shariah does not set any guideline in profit-taking method or rate, however there is a signal indicating that the imposition of profit should be taken at a reasonable rate and not burdensome till doubled dan multiplied (ad'afan muda'afah). Among the recommended guidelines are the price of goods should be set at market price; the profit-taking rate should be based on local custom, that is, for instance, double the capital price; the government can also control the price of goods by pronouncing a ceiling price and the level of profit taken by entrepreneur should be controlled so that the price of goods can be stabilized in the market and manipulation can be avoided. In addition, some of the profit-taking can be at half-, double- or triple-rate basis according to the market price or additional cost incurred. However, if the price is multiplied more than four of five fold, then it can lead to the implication of oppression and persecution. This argument is clear and has been supported by authorized shariah sources of the Quran and Hadith as well as from the perspective of maqasid shariah, wasatiyyah, and ihsan. Hence, despite the fact that the Islamic law does not set a profit-taking rate, but implicitly, by following authentic shariah sources and methods, obviously there is a certain rate can be imposed in setting the profit-taking rate.

\section{Corresponding Author}

Jasni Sulong

School of Humanities, Universiti Sains Malaysia, 11800 Pulau Pinang, Malaysia

Email: jasni@usm.com 
INTERNATIONAL JOURNAL OF ACADEMIC RESEARCH IN BUSINESS AND SOCIAL SCIENCES

Vol. 8, No. 7, July 2018, E-ISSN: 2222-6990 @ 2018 HRMARS

\section{Acknowledgment}

This study was conducted under the funding of the Fundamental Research Grant Scheme Phase 1/2017, No. 203 / PHUMANITI / 6711589.

\section{References}

Astro, A. (2018). Kos sara hidup isu keempat paling dibimbangi rakyat Malaysia - kajian. http://www.astroawani.com/berita-politik/kos-sara-hidup-isu-keempat-paling-dibimbangirakyat-malaysia-kajian-173238. (accessed on 16/3/2018).

Bank Negara Malaysia (2015). Annual Report 2015. https://www.bnm.gov.my/files/publication/ar/en/2015/ar2015_book.pdf. (accessed on 16/3/2018).

Bukhari, M. I. (1422H). Sahih al-Bukhari. Jiddah: Dar Tauq al-Najah.

Dewan, K. (2010). Kuala Lumpur: Dewan Bahasa dan Pustaka.

El-Islamy, H. (2014). Mengkonvensionalkan Perbankan Islam. Muzakarah Penasihat Syariah Kewangan Islam Kali ke-9 (p. 1-12). Kuala Lumpur: Islamic Finance Forum.

Faridah, H. T. Z. (2011). Al-Riqabah 'ala al-Sila' wa al-As'ar fi al-Fiqh al-Islami. Thesis Master. Department Fiqh and History. Palestin University.

Ghazali, M. M. (1997). al-Mustasfa fi ‘llm al-Usul. Beirut: Muassasah al-Risalah.

Hasan, A. (2006). Al-Tas'ir fi al-Fiqh al-Islami. Majallah Jami'ah Dimasyq li al-'Ulum al-lqtisadiyyah wa al-Qanuniyyah, 22(1), $455-473$

Hashem. A. O. (n.d.). Moderation in Islam. London: United Printing Publishing \& Distributing.

Ibn Khaldun, A. R. (1958). The Muqaddimah: an introduction to history; in three volumes. 1 (No. 43). Princeton University Press.

Ibn Majah, M. Y. (2009). al-Sunan. Beirut: Dar al-Risalah al-'Ilmiyyah.

Ibn Qudamah, A. A. (1405H). Al-Mughni. Beirut: Dar al-Fikr.

Ling, C. S., Almeida, S. J., Wei, H. S. (2017). Rumah Mampu Milik: Cabaran dan Langkah Ke Hadapan, BULETIN SUKU TAHUNAN BNM 2017, http://www.bnm.gov.my/files/publication/qb/2017/Q4/p3_ren1_bm.pdf (accessed on 25/3/2018)

Madkur, I. (n.d.). al-Mu'jam al-Wasit. Turkey: Dar al-Da'wah.

Malik, A. (n.d.). Mudawwanah al-Kubra. Beirut: Dar al-Sadir.

Mazuki, A. A. M., Mujani, W. K., Aziz, A., \& Rozali, E. A. (2013). Application of The Wasatiyyah Concept To The Formation of the Medina Charter. International Journal of West Asian Studies, 5(2), 1 15.

Mohamad Yusof, M. F., Hamzah, Z. A. Z., Maming, P. H., \& Yaakob, N. A. (2015). Intertekstualiti dalam Wacana Muamalat. International Journal of the Malay World and Civilisation (Iman), 3(1), 91 105.

Mohamad, S. (2002). Ciri-ciri Keuntungan Menurut Perspektif Islam. Jurnal Syariah, 10(1), 121-137.

Muhammad Idris, R. (2002). "Perkembangan Sistem Perbankan dan kewangan Islam di Malaysia”, in Nik Mustafa Nik Hassan (eds.), Ekonomi Islam dan perlaksanaannya di Malaysia. Kuala Lumpur: Institut Kefahaman Islam Malaysia.

Muhammad, W. (2007). Musawwaghat Istihqaq al-Masraf al-Islami li al-Ribh fi 'Amaliyyah alMurabahah li al-Amir bi al-Syira'. Dirasat, 'Ulum al-Syari'ah wa al-Qanun, 34(1), 40 - 52. 
INTERNATIONAL JOURNAL OF ACADEMIC RESEARCH IN BUSINESS AND SOCIAL SCIENCES

Vol. 8, No. 7, July 2018, E-ISSN: 2222-6990 @ 2018 HRMARS

New Straits Times. (2017). Cost of living a major concern among Malaysian public, survey found. https://www.nst.com.my/news/nation/2017/10/294580/cost-living-major-concern-amongmalaysian-public-survey-found . (accessed on 16/3/2018).

Qaradawi. Y. (1997). Wasatiyyah fi al-Islam. Cairo: al-Azhar.

Qaradawi. Y. (2012). Ciri-ciri Unggul Masyarakat Islam Yang Kita Idamkan. Kuala Lumpur: Penerbitan Seribu Dinar Sdn. Bhd.

Rawwas, M. (2002). al-Muamalat al-Maliyah al-Muasarah. Jordan: Dar al-Nafais

Razi, M. U. (1420H). al-Tafsir al-Kabir. Beirut: Dar Ihya al-Turath al-'Arabi.

Saleh, A. M., al-Kharabshah, A. R., al-Kinani, A. M. (2012). Tahrir al-Nuqul fi 'llmi al-Usul. Amman: Jami'ah al-Yarmuk.

Saudi Fatwa Institute. (2018). Fatwa Nur 'Ala al-Darb: Hukm Tahdid al-Maksab fi al-Tijarah, 19/50, http://www.alifta.net/Fatawa/FatawaChapters.aspx?languagename=ar\&View=Page\&PagelD= 5361\&PageNo=1\&BookID=5 (accessed on 7/3/2018).

Syatibi, I. M. (1997). al-Muwafaqat. Sa'udi: Dar Ibn ‘Affan.

Syawkani, M. A. (1993). Nail al-Awtar. Qaherah: Dar al-Hadith

Tabari, I. J. (1980). Jami' al-Bayan fi tafsir al-Quran. Beirut: Dar al-Ma'rifah.

Taimiyyah, I. (n.d.). Majma' Fatawa. Saudi: Dar al-Wafa'

Waghe, N., Bosley, M., Gardiner, T., Pannell, H. (2015). Excessive Prices and Profitability. Competition Law Insight, 14(4), 1-9.

Ya'qubi, M. A. H. (2000). Ahkam al-Tas'ir fi al-Fiqh al-Islami. Beirut: Dar al-Basya'ir al-Islamiyyah.

Yahaya, S. R. (1985). Konsep Asas Ekonomi. Kuala Lumpur: Dewan Bahasa dan Pustaka.

Zuhaili, W. (2011). Al-Tafsir Al-Munir Fi Al-Aqidah Wa Al-Syariah Wa Al-Manhaj. Dimasyq: Dar al-Fikr. 